\title{
A JELENLÉT NÉLKÜLI JELEN(LÉT) - A HAZAI PÁRTSZERVEZETEK FEJLETTSÉGÉNEK TERÜLETI KÜLÖNBSÉGEI
}

\author{
BÓDI MÁTYÁS \\ SPATIAL INEQUALITIES IN THE INSTITUALIZATION OF HUNGARIAN \\ POLITICAL PARTIES
}

\begin{abstract}
Numerous studies draw a direct link between party institutionalization and democratic (re) consolidation. The level of organization of a given political movement can easily determine their subsequent electoral performance. Not just in Hungary, but within the wider Central-EasternEuropean region, accessing data on party membership, branch offices, etc., is extremely challenging, therefore concluding or discovering party organizational strength is a critical research area. In this study I am making a bold attempt to unveil the social embeddedness of the most important political parties from the 2014 general elections to the latest EP elections (2019), by using the polling station table-seater delegates presence as an indicator of local party presence itself. I assume that, if a given party is not able to delegate a single person to a certain polling station, they have no operating organizations at the grassroots level, therefore it indicates their lack of localization and extensive network. With simple quantitative methodologies, I was also seeking the relationship between electoral performance and party organizational presence locally.
\end{abstract}

Keywords: electoral geography, party organizations, political geography

\section{Bevezetés}

A különböző hazai választásföldrajzi kutatások alaposan feltárták társadalmunk választói magatartásának térbeli jellegzetességeit. A társadalomtudományok által jól beazonosított politikai gondolkodásbeli törésvonalak (ENYEDI Zs. - KÖRÖSÉNYI A. 2001) térbeli mintázatai mentén, bizonyos mértékig tettenérhetőek és magyarázhatóak a pártpreferenciális, illetve egyéb voksolási jellegzetességek, amelyek akár választásról-választásra visszatéróen kirajzolódnak (KovÁcs Z. 1991; HAJdú Z. 2006; JANKÓ F.-KOMORNOKI M. 2008; BóDI F.-Bódi M. 2011; Vida Gy.-Kovács Z. 2017; Vida Gy.-KovalcsiK T. 2018, stb.). Ezen kutatások fontos társadalmi összefüggéseket tárnak fel - ennek kapcsán említhetnénk a város-vidék dichotómia továbbélését a jobb-bal tengely mentén (VIDA GY.-Kovács Z. 2017) - amelyeken keresztül könnyebben érthetőbbé válnak a hazai politikai folyamatok is.

Ebben a tanulmányban arra tettem kísérletet, hogy a hazai pártok szervezeti fejlettségét, intézményesültségét, helyi társadalmi beágyazottságát mutassam ki, különös tekintettel a vizsgált jelenség területi jellegzetességeire. Arra keresem a választ, hogy az általam vizsgált négy, országos jelentőségú választási esemény (országgyuulési: 2014, 2018, Európai Parlamenti: 2014,2019) vonatkozásában, a felállított településkategóriák szerinti felosztásban, valamint a 106 országos egyéni választókerület (OEVK) szintjén mely pártok voltak képesek vizsgálatra érdemes számú pártdelegáltat eljuttatni a szavazóköri szavazatszámláló bizottságokba. Ahogyan azt a hasonló célú nemzetközi vizsgálatok is mutatják, pártok szervezeti állapotára vonatkozó adatokat (pl. párttagok száma és lokációja, alapszervezetek elhelyezkedése) szinte képtelenség megszerezni, ezért meglátásom szerint az egyetlen olyan hiteles adatot használtam fel, amely a Nemzeti Választási Iroda (NVI) szavazóköri jegyzőkönyveiben rögzített. 
Egy rövidebb nemzetközi szakirodalmi áttekintést követően, melyben szerettem volna a helyi pártjelenlét és az eredményes választási szereplés közötti összefüggés elméleti alapjait lefektetni, megvizsgálom, hogy a szavazóköri pártdelegáltak jelenléte, milyen területileg kitapintható jellegzetességekkel bír. A tanulmány záró részében pedig az egyes pártok szavazóköri jelenlétét megpróbálom összefüggésbe hozni az adott szavazókörben elért választási eredményével, ezáltal empirikusan megvizsgálni, hogy valóban kimutatható-e összefüggés a két változó között. Végezetül ezeket az összefüggéseket egy kormány - ellenzék szembeállításban is elemzem. A választási eredményeket az adott pártra leadott listás szavazatok százalékában mértem.

\section{Választási földrajzi kutatások és a területiség szerepe a hatalom megszerzésében}

A választási eredmények térbeli elemzésének van egy tisztán hatalomtechnikai aktualitása is. A választási törvény 2011-ben megkezdett módosításainak eredményeként a vegyes választási rendszer ugyan megmaradt, de annak többségi elemei rendkívül felerősödtek (SzIGETı P. 2013; Tóтн Cs. 2017), mivel a parlamenti mandátumok több mint felének sorsáról,immáron az egyéni választókerületekben döntenek a választópolgárok. Nem beszélve arról a legfeljebb nyelvi oximoronként értelmezhető, ún. ,győztes-kompenzációs” töredékszavazat-számítási mechanizmusról, amely szintén a választókerületi jelöltekre leadott voksokra vezethető vissza.

Legszemléletesebb metaforát a többségi karakter jelentőségéről Tölgyessy Péter, a rendszerváltás során konszenzuálisan elfogadott korábbi választási rendszer egyik szellemi atyja tudta megalkotni, amikor ahhoz a játszótéri libikókához hasonlította azt, amely amint átbillen az egyensúlyi ponton, hatalmas erővel csapódik a földbe (TöLGYESSY P. 1015).

Ennek megfelelően felerősödött egy olyan gondolkodásmód a helyi hatalom gyakorlói részéről is, amelyben az országgyúlési választókerület vált azzá a területi egységgé, amin belül területfejlesztési terveiket elképzelik (PÁLNÉ KovÁCs I. 2019), alapvetó politikai stratégiáikat felépítik. Ez már csak azért is egy teljesen abszurd hatalmi megközelítés, mivel az országgyúlési választókerületek határai, számos esetben még a területi politikai rendszer alapegységeinek tekinthető önkormányzatok (KÁKAI L.- VETő B. 2019) közigazgatási határaira sincsenek tekintettel (pl. Miskolc, Pécs, Szeged, Nyíregyháza esetében), jóllehet ez az előző választási rendszernek is egyfajta sajátossága volt.

Napjainkra, az ismételten gyakorlatilag kétpólusúvá váló hazai politikai színtéren, az egyéni választókerületi küzdelmek tehát felértékelődnek, arról nem is beszélve, hogy az ún. győztes-kompenzáció bevezetését követően, a nyertesek a választókerületekből is tudják gazdagítani a listás szavazattömeget. 2018-ban ennek pl. döntő jelentősége volt a kormánypárt ismételt kétharmados győzelmében (LÁszLó R. 2018). Mindezek ismeretében nem meglepő, hogy a hazai nyilvánosságban mára olyan észak-amerikai terminusokkal is találkozhatunk, mint a magyar „swing-state”, vagy „,szupercsatatér” (STUMPF A. 2021) körzetek kifejezése. A választókerületek, az ott élő választópolgárok minél átfogóbb ismerete tehát kulcsfontosságú a jelenlegi választási szisztémában.

A fentiek okán, valamint a soron következő 2022-es országgyúlési választásokra való tekintettel is, indokolt az általam felvezetett vizsgálat lefolytatása, hiszen pont azt mutatom be a használt indikátor segítségével, hogy mely pártok, illetve a kormány - ellenzék viszonyában, melyik szereplő rendelkezik az adott OEVK-ban jobban kiépült pártszervezettel. Mindazonáltal, retrospektív jelleggel azt is tanulmányozom, hogy az adott OEVK-n belül mért magas szavazóköri delegálási potenciál magával hozta-e a párt jobb választási szereplését, mivel a felhasznált nemzetközi tanulmányok ennek a hipotézisnek a megerôsítésére engednek következtetni. 


\section{Pártszervezetek és azok lokális jelentősége}

A választási eredmények területi szempontú vizsgálata tehát széles körben ismert kutatási irány. Ebben a tanulmányban azonban arra szeretnék kísérletet tenni, hogy a hazai politikai pártok intézményesültségét, társadalmi beágyazottságát, szervezeti fejlettségét vizsgáljam meg hasonló megközelítésben. Ezt azért is tartom egy fontos gondolatkísérletnek, mert a már említett kétosztatú politikai színtér ellenzéki oldala egy rendkívül heterogén politikai közösségből épül fel. Török Gábor politológus úgy fogalmazta ezt meg a 2019es önkormányzati választások másnapján, hogy az „...ellenzéki politika ma egy felhó”, amiben rendkívül sokfajta szereplő van, nem csak kizárólag pártok (TöRöK G. 2019). Ezen csoport szereplői, mint ahogyan azt a későbbiekben igyekszem érzékeltetni, nagyon különböző érettségú és stratégiájú szervezetek halmaza, amelyek intézményi fejlettsége, lokális fizikai jelenléte területileg is nagyon differenciált képet mutat.

A hazai és a nemzetközi szakirodalomban egyaránt szakmai konszenzus övezi azt a megállapítást, mely szerint, pártok választási sikerének egyik alapfeltétele a jól kiépült szervezet vagy országos lefedettséggel rendelkező tagság, aktivista hálózat (például: TAVITS M. 2012, 2014; Gerghina S. 2014; Riberio P.F.-LOCATElli F. 2019; HaLVORSEN S. 2019, SCOTt J.WiLLS J. 2017). Természetesen létezik egy sor egyéb olyan szempont is, amelyek az adott politikai kontextustól függetlenül döntőek lehetnek, mint például az adott párt strukturális felépítése (központosított és vezérelvű, vagy inkább bázisdemokrata). Többen azt is kiemelik, hogy egy harmonizált térszerkezettel rendelkező pártstruktúra jelentősen hozzájárulhat ahhoz, hogy az adott politikai közösségen belül, kellő mértékben legyenek reprezentálva és artikulálva az ország különböző vidékeinek társadalmi problémái, ami szintén egy sikeres párt alapfeltétele (Scott J.-WiLls J. 2017, az olasz Öt Csillag Mozgalom példáján: MikolA-Oross 2018).

A politikatudomány számára különösen érdekes vizsgálati terepet jelentenek a fiatal demokráciák, az ott létrejövő pártosodás társadalmi jelenségei. (Szubszaharai-Afrika államai kapcsán: BASEDAU M.-STROH A. 2008, Dél-Amerika országai kapcsán: RiBERIO P.F.-LOCATELLI F. 2019, a posztszocialista európai országok kapcsán: TAVITS M. 2012; Gerghina S. 2014; Pete M. 2016). Mindazonáltal rendkívül tanulságos munkák születtek a legnagyobb múltra visszatekintő parlamentarizmusban, Nagy-Britanniaban is, különös tekintettel a Munkáspárt helyi közösségépítési gyakorlatára támaszkodó szervezetfejlesztésére (ScOTT J.-WILLS J. 2017). Ezeket megelőzően átfogó elemzések láttak napvilágot az Egyesült Államok kapcsán egyaránt (FRENDREIS J. P. et al. 1991). Ezen munkák túlnyomó többsége azonban nem kísérelik meg az országos szintnél granulárisabb nézópontok érvényesítését, habár üdítő kivételek léteznek, azonban azok szerzői is többnyire politikai földrajzzal foglalkozó geográfusok (Argentína kapcsán: HALVORSEN S. 2019). Nem tudhatjuk meg belőlük, hogy az adott politikai mozgalmak mennyire tudtak gyökeret ereszteni a vizsgált országok különböző térségeiben. Márpedig, ha elfogadjuk, azt az alapvetést, mely szerint a sikeres párt receptje a kiterjedt tagság és kiépült pártszervezet, pártirodák hálózata, akkor szükségképpen nem elégedhetünk meg egy általános országos képpel hazánk esetében sem. Miközben azonban finoman kárhoztatjuk a politikatudományt a területi dimenzió negligálásáért, nem mehetünk el szó nélkül amellett, hogy a megszerezhetô adatok tekintetében egy rendkívül érzékeny kutatási területről beszélünk. Politikai mozgalmak, pártok, nem szívesen adnak ki információkat a tagságukkal, alapszervezeteikkel, pártirodáik lokációjával kapcsolatosan, ami különösen igaz azokra az országokra, amelyek valamilyen önkényuralmi rendszer igája alól, relatíve frissen szabadultak fel (TAVITS M. 2012). Az általam hivatkozott észt származású amerikai politológus, Margit TAVITS például ennek áthidalására az önkormányzati választások egyéni jelöltjeinek párt 
színezetét vette alapul számitásaiba hazánk és Lengyelország esetében (TAVITS M. 2012. és 2014.), feltételezvén, hogy ha egy párt legalább egy jelöltet képes kiállítani helyi szinten, azzal kimutatható a párt jelenléte is.

Az általam vizsgált időszak hazai főszereplőinek pártszervezeti fejlődése, szintén alaposan feltárt kutatási terület (MSZP kapcsán: LAKNER Z. 2017; Fidesz: ENYEDI Zs. 2004; BÉKÉS M. 2008; BALÁZS Z.-HAJdú A. 2017, valamint rendszerszinten átfogó jelleggel: KÖRÖSÉNYI A. et al. 2020; Jobbik: RóNA D. 2016). Területileg differenciált adatokkal vagy megállapításokkal ezekben sem találkozunk ugyan, de a pártszervezetek belső állapotáról, vagy azok korábbi kialakítása, fejlesztése kapcsán nagyon alapos kutatásokat végeztek a szerzők. Külön említést érdemel Tóka Gábor korai munkája (TóKA G. 1991), melyben a harmadik magyar köztársaság, elsô szabadon megtartott önkormányzati választása során, a pártok jelöltállítási potenciálját vizsgálva próbál következtetni a pártszervezetek fejlettségére. Ez ugye a Tavits féle 2012-es nemzetközi kutatás módszertanára emlékeztető, azonban azt messze megelőző vizsgálati megközelítés volt.

Egy másik, alapvetően Magyarországra sajnálatosan nagyon jellemző kutatási problematika, a magyar társadalom, tömeges (politikai) állampolgári részvételének nagyfokú hiánya, amely már a harmadik magyar köztársaság kezdeti legitimizációs válságát is okozta (TÖLGYESSY P. 2019). Ennek, vizsgálatunkból fontos szempontja, a pártok, nemzetközi összehasonlításban is alacsony taglétszáma (RIBERIO P.F.-LOCATELLi F. 2019). Egykoron gyakorló politikus-pártelnök megfogalmazásában ugyanez, így hangzik: „Az állampolgári részvétlenség az ezredfordulóra (...) válságba sodorta a magyar politikai rendszert. A pártok kiürültek, elveszítették képességüket, hogy tényleges társadalmi érdekeket aggregáljanak, magyarul rendeltetésszerüen müködjenek." (SCHIFFER A. 2017).

\section{A pártok társadalmi beágyazottságának egy lehetséges merőszáma - A vizsgálat módszertana}

A választási eljárásról szóló törvény (2013. évi XXXVI. törvény a választási eljárásról 28. § (4), illetve 29. §) értelmében a választások alkalmával a szavazatszámláló bizottságokba (szavazókörökbe) az adott választókerületben jelöltet állító, vagy országos listával rendelkező pártok is delegálhatnak 2-2 szavazatszámláló biztost (pártdelegáltak), valamint a függetlenként induló egyéni jelöltek számára is nyitva van ez a lehetőség. A pártok számára fontos a szavazóköri jelenlét, a szavazatszámlálás folyamatának felügyelete. Erre még a választások során annak tisztaságát felügyelő nemzetközi szervezetek (EBESZ, Velencei Bizottság) is kitérnek a választási események ról szóló beszámolójukban (EBESZ/ODIHR. 2014 és 2018). Hazánkban nagyjából 10 ezer szavazókörben bonyolítják le a választásokat. Ez a szám az országgyúlési választások alkalmával pár 100 szavazókörrel több, az EP voksolások alkalmával kevesebb. Nyilvánvalóan annak megszervezése, hogy a választás napján a közel 10 ezer szavazókör mindegyikébe legalább egy, de ideálisabb esetben (gondolva a mozgó urnáztatásra is) két delegáltat el tudjon juttatni egy párt, elképesztően nehéz feladat, melyet csak egy komoly szervezeti háttérrel rendelkező politikai erő képes megoldani.

Az egyes pártok szervezeti fejlettségének tettenérésére a fentiek okán a választások alkalmával a szavazókörökbe megjelent pártdelegáltak adatait vettem alapul. A kormány - ellenzék összehasonlítás során figyelmen kívül hagytam a különböző anyagi haszonszerzés és egyéb „zavarórepülés” céljából létrehozott alkalmi szervezeteket, azonban azon független jelöltek (pl. dr. Mellár Tamás, Kész Zoltán) delegáltjait az ellenzékhez soroltam, akik nyíltan az ellenzéki pártok támogatását élvezték. A 2014-es parlamenti voksolás alkalmával, az Összefogás pártjai (MSZP, DK, Együtt, Párbeszéd, Magyar Liberális Párt) 
közös listán és közös egyéni jelöltekkel vágtak neki a küzdelemnek, így a választási törvénynyel összhangban, a pártdelegáltak is eképpen szerepelnek az NVI szavazóköri jegyzőkönyveiben. Természetesen a pártdelegáltak nem szükségszerúen párttagok, azonban vizsgálatom szempontjából éltem azzal a feltételezéssel, hogy egy párt ilyetén megnyilvánuló képviselete erős szervezeti kapcsolatot feltételez. Számos beszélgetést folytattam aktív politikai szereplőkkel, akik a vizsgálatom tárgyát kepéző pártok operatív feladatait látják el. Egybehangzóan megerősítették, hogy a pártdelegáltak számára a választásokat megelőzően tájékoztató anyagokkal, képzésekkel készülnek, amelyek több alkalmat is felölelnek. Ebből arra következtettem, hogy ezek az emberek az adott pártokhoz szorosan kötődo, azok felé elkötelezett, és ami a legfontosabb, szervezetileg is kapcsolódó helyi szereplők. Természetesen egy adott településen a választás napján ilyenformán szolgálatot teljesítő delegált nem szükségszerúen az adott település lakója. Mindazonáltal azt szintén megerôsítették a pártok, hogy jellemzően ezek a pártdelegáltak nem mozgathatók saját településüktől messzire.

A vizsgálatba, a legutóbbi két országgyúlési $(2014,2018)$ valamint szintén két európai parlamenti $(2014,2019)$ voksolás adatait használtam fel, amelyet az NVI bocsátott rendelkezésemre, szavazóköri szinten. Az önkormányzati választások adatait, a pártfüggetlen jelöltek rendkívül magas és településmérettől függő száma miatt nem használtam fel ebben a vizsgálatban. Az adatokat települések, valamint országos egyéni választókerületek (OEVK) szintjére aggregáltam (EP voksolások esetén, a címnyilvántartás alapján önkényesen), majd előbb horizontálisan, tehát települések jogállása és lakónépessége alapján kialakított kategóriák szerint vizsgálódtam. Ezt követően, OEVK szinten folytattam az elemzést. Már az adatok feldolgozásának kezdeti szakaszában felmerült, hogy érdemes lenne egy kormány - ellenzék összehasonlítást retrospektív jelleggel is felállítani a vizsgált választási események kapcsán. Habár 2014-re egyértelmúen hárompólusúvá vált a hazai politikai színtér (VIDA GY.-KovÁCs Z. 2017), a jelenlegi politikai kétosztatúságra, amely a 2019-es önkormányzati választások idejére intézményesült formában is testet öltött, valamint a 2022-es országgyuulési választásokra tekintettel tartottam szükségesnek ezt a fajta distinkciót. Mindezeken felül, beazonosítottam azokat a szavazóköröket is, amelyekbe kizárólag a kormánypárt tudott delegáltat eljuttatni. Ezt azért tartottam szükségesnek, mert a Fidesz-KDNP delegálási potenciálja magasan kiemelkedik a mezőnyből, mind a négy vizsgált esemény, de különösen az EP választások során (2014-ben a szavazókörök 21\%-ban, 2019-ben már a 25\%-ban kizárólag a kormánynak volt pártdelegáltja). Ami viszont még ennél is tanulságosabb, hogy ezt a logisztikai feladatot úgy tudta megoldani, hogy mindeközben földrajzilag rendkívül egyenletesen fedte le az ország szinte teljes egészét. Ezzel szemben az ellenzék pártjai, számos esetben alig voltak képesek megjelenni az ország egyes, egymással földrajzilag összefüggő vidékein.

A településtípus szerinti horizontális, majd EOVK szintű elemzést követően, a kapott szavazóköri pártdelegált eredményeket összevetettem a választások, pártlistákra leadott szavazati eredményeivel. Ezzel szeretném megvizsgálni azt a hipotézist, mely szerint az erős pártszervezeti jelenlét (tehát esetünkben, a pártdelegáltak száma), összefüggésben áll a párt választási eredményességével, ahogyan azt több nemzetközi tanulmány is állítja (TAViTs M. 2012; ScotT J.-WiLls J. 2017). Az egyéni jelöltekre leadott szavazatok nem képezik ennek a vizsgálatnak a tárgyat, hiszen az EP választások alkalmával csak listákra szavazunk. Továbbá 2018-ban a taktikai szavazás jelensége, mint országos szinten precedens nélküli választópolgári stratégia (VIDA Gy.-KovALCSIK T. 2018) erősen torzítja az eredményeket, nem beszélve a DK - MSZP, OEVK szinten köttetett választási koordinációs együttmúködésről 2018-ban.

A területi szint megválasztása kapcsán, fontos kiemelni, hogy a 2014-ben debütáló új választási rendszerben, az alkalmazott új földrajzi lehatárolás aránytalanságai („malapportionment”, ,garrymendering”), „földrajzi torzulásai” (VIDA Gy. 2020), némileg deter- 
minálták vizsgálatom egyes eredményeit. Ez elsősorban annak volt köszönhető, hogy a kormánypártok támogatottsága immáron egyenletesebben oszlott el a választókerületek között. Ezzel szemben, a baloldali pártok szavazóinak térbeli eloszlása, 2014-rôl és 2018-ra, egy erős térbeli koncentráción ment keresztül az urbánusabb kerületek javára (VIDA Gy. 2020), amit, mint azt a következőkben be is mutatom, követett a baloldali pártdelegáltak folyamatos kiszorulása a vidéki szavazókörökből is. A „garrymendering” torzító hatása, még a térben harmonikusabb támogatottsággal bíró Jobbikkal kiegészült ellenzékkel szemben is, a jelenlegi kormányzópártoknak kedvezne egy kétosztatú politikai küzdelem során.

\section{Pártjelenlét a választások napján a településméret függvényében}

A vizsgált négy választás alkalmával a Fidesz-KDNP kimagasló hatékonysággal tudta „benépesíteni” a magyarországi szavazóköröket. Ha úgy tetszik, ennek a képzeletbeli pártok közötti versenynek (is) a kormánypártok az abszolút győztesei. A leggyengébb országos adatot a 2018-as országgyúlési választás alkalmával produkálta a párt, ekkor „csupán” a szavazókörök 95\%-ában volt jelen. Kissé meglepő, hogy olyan szavazókörök jegyzőkönyveiben sem találni kormánypárti delegáltat ekkor, mint például egy kivételével az összes mohácsi (ellenben a DK delegáltja jelen volt mindegyikben), vagy Nyíregyháza több tucat szavazóköre, ahol viszont az NVI adatai alapján az ellenzéknek sem volt képviselője. A többi vizsgált választás alkalmával ez a szám rendre 98-99\% körül mozgott. Településtípusonkénti bontásban vizsgálva szinte alig látunk eltérést (1.táblázat), azonban az szembetűnő, hogy a településhierarchia legalacsonyabb fokain, már az amúgy elképesztő hatékonysággal múködő pártszervezetnek is voltak relatív logisztikai nehézségei (500 fó alatti kategóriában 2018-ban: 76\%). Ezt leszámítva, a kormánypártok teljesítményét még csak megközelíteni sem tudta egyetlen ellenzéki szervezet sem. Ellenzéki térfélen a leghatékonyabban delegáló párt vagy pártszövetség kiléte választásról választásra változott.

1. táblázat - Table 1

Pártdelegáltak a szavazókörök \%-ában a legutóbbi két országgyűlési választás alkalmával, településtípusonként.

Party delegates in \% of polling stations in the last two parliamentary elections, by type of municipality.

\begin{tabular}{c|cccc|ccccc}
\hline & \multicolumn{4}{|c|}{ 2014 Országgyúlési } & \multicolumn{5}{c}{ 2018 Országgyúlési } \\
& Fidesz Jobbik & $\begin{array}{c}\text { Össze- } \\
\text { fogás }\end{array}$ & $\begin{array}{c}\text { csak } \\
\text { Fidesz }\end{array}$ & Fidesz & Jobbik & MSZP & DK & csak \\
Fidesz
\end{tabular}

* Budapest nélkül

Forrás: NVI, saját szerkesztés

Source: NVI, own compilation 
A 2014-es Összefogás a szavazókörök 85\%-ban jelen volt ugyan az országgyúlési választásokon, azonban 2018-ra a leghatékonyabb ellenzéki szervezet szerepét egyértelmúen átvette a Jobbik (70\%). A baloldali pártok esetében különösen meghatározó volt a településméret. Saját országos átlagukhoz képest sokkal alacsonyabb hatékonysággal tudták képviseltetni magukat az 5 ezer főnél kisebb népességű településeken. A baloldali tömbön belüli differenciáltság már a 2014-es EP választás vizsgálatával tapintható ki igazán, ugyanis itt már külön listán indultak ezek a pártok. Szembeötlő, hogy az 5 ezer fónél kisebb lakosságú településeken a szocialisták rendelkeztek nagyobb arányban szavazóköri delegáltakkal, míg ugyan itt a DK és az Együtt-PM emberei szinte alig voltak jelen. A 2018-as választásokra ez a kép döntően nem módosult, mivel az MSZP kétszer annyi szavazókörben volt jelen, mint a DK, amelynek még továbbra is jelentős akadályt jelentett a községi jogállású településeken történő reprezentáció (8\%), míg ezzel szemben a fővárosi szavazókörök már több mint 40\%-ban fel tudott vonultatni delegáltat.

A 2019-es EP választás eredménye alapvetôn átrendezte az ellenzéki térfél politikai erőviszonyait, a DK érezhetően előrébb tudott lépni az alacsonyabb népességú települések szavazóköreiben a delegálást illetően is (2. táblázat). Érdemes azt is kiemelni, hogy a Demokratikus Koalíció volt az egyetlen ellenzéki parlamenti párt, amely abszolút számban több delegáltat tudott eljuttatni a legutóbbi EP választás alkalmával az urnák mellé, mint az azt megelőző 2018-as országgyúlési választáson. Ehhez persze kellett a Jobbik példátlan mértékú szervezeti visszaesése is 2019-re. Mindazonáltal nagyon fontos kiemelni, hogy a Magyar Szocialista Párt, a szavazóköri delegálásokat illetően az egyetlen olyan szereplője a magyar politikai színtérnek, amely a Fidesz mellett (habár kisebb mértékben és településmérettől függóen differenciáltan) valamilyen fajta állandóságot és szervezeti stabilitást tudott felmutatni választásról választásra (közel 50\%-os delegálás országos mind a négy választáson).

2. táblázat - Table 2

Pártdelegáltak a szavazókörök \%-ában a legutóbbi két Európai Parlamenti választás alkalmával, településtípusonként.

Party delegates in $\%$ of polling stations in the last two European Parliament elections, by type of municipality.

\begin{tabular}{|c|c|c|c|c|c|c|c|c|c|c|c|c|c|}
\hline & \multicolumn{6}{|c|}{2014 EP } & \multicolumn{7}{|c|}{2019 EP } \\
\hline & 胥 & 光 & 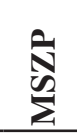 & 光 & 点 & 卷 & $\frac{2}{0}$ & 商 & $\sum_{\Sigma}^{\infty}$ & $\underline{a}$ & 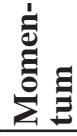 & 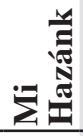 & 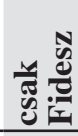 \\
\hline Budapest & 99,9 & 77,7 & 72,8 & 24,4 & 18,4 & 2,3 & 99,1 & 28,3 & 67,2 & 53,1 & 10,8 & 7,6 & 2,8 \\
\hline $20000-*$ & 99,4 & 66,7 & 66,0 & 13,3 & 10,6 & 6,1 & 100,0 & 33,0 & 65,5 & 31,9 & 4,2 & 7,0 & 7,8 \\
\hline $10000-20000$ & 98,6 & 70,3 & 66,4 & 17,3 & 4,7 & 5,3 & 99,0 & 37,7 & 57,5 & 30,9 & 1,5 & 6,3 & 12,6 \\
\hline $5000-10000$ & 99,7 & 66,8 & 54,5 & 11,0 & 3,6 & 13,2 & 100,0 & 33,0 & 42,6 & 27,9 & 1,5 & 2,7 & 25,7 \\
\hline $1000-5000$ & 98,4 & 46,7 & 39,4 & 8,4 & 3,5 & 29,4 & 98,2 & 26,8 & 34,0 & 18,5 & 0,7 & 4,0 & 35,1 \\
\hline $500-1000$ & 97,4 & 28,5 & 27,3 & 6,9 & 2,5 & 47,5 & 99,6 & 15,6 & 19,6 & 12,5 & 0,7 & 2,7 & 58,7 \\
\hline-500 & 98,1 & 11,0 & 13,5 & 2,6 & 0,3 & 74,9 & 96,8 & 10,4 & 9,1 & 5,4 & 0,1 & 1,5 & 76,5 \\
\hline Magyarország & 98,9 & 55,6 & 51,7 & 12,5 & 7,2 & 21,5 & 99,0 & 28,1 & 47,0 & 27,4 & 3,1 & 5,1 & 25,6 \\
\hline
\end{tabular}

* Budapest nélkül

Forrás: NVI, saját szerkesztés

Source: NVI, own compilation 
A Jobbik a legutóbbi EP voksolást leszámítva, rendkívül fontos szerepet tölthetett be az ellenzék szempontjából a szavazókörökben. A jobbikos alapszervezetek azért is lehettek fontosak, mert a baloldali pártokkal ellentétben a településhierarchián lefelé lépkedve, nem jellemezte őket az azzal arányos alulreprezentáltság. A Jobbik jelölési potenciálja jellemzően a közepes méretû településeken volt a legerősebb (pl. 5-20 ezer fós települések esetében magasan 80\% feletti szavazóköri jelenlét 2018-ban, de az 500 fónél alacsonyabb lélekszámú aprófalvas szavazókörök több mint negyedében is jelen volt a párt). Ugyanakkor a 2019-es EP választásokra már rendkívül kedvezőtlen szervezeti feltételek mellett voltak kénytelen nekifutni (Vona Gábor visszavonulása, milliárdos ÁSZ büntetés, a Mi Hazánk alapítótagjainak kiválása stb.), ami a delegálási potenciáljukra is erősen rányomta a bélyegét. A Jobbik 2019-ben mindössze a szavazókörök alig több mint negyedében tudott megjelenni, azonban ezt nem magyarázza a Mi Hazánk létrejötte, amely a szavazókörök mindössze 5\%-ban bukkant fel.

Említést érdemel még egy jelenség, ami viszont teljesen kontextus nélküli vizsgálatunk szempontjából és talán kissé rámutat annak egyik módszertani fonákságára is. A 2014-es országgyúlési választások szavazóköri jegyzőkönyveinek összesített adatai alapján a Fidesz, az Összefogás és a Jobbik hármast követôen, a negyedik legtöbb szavazatszámláló delegáltat (1179 fó, 802 szavazókörben) a Magyarországi Cigánypárt (MCP) tudta mozgósítani, ami azért is meglepő, mert a párt listán mindössze 8793 szavazatot kapott. Csak összevetésképpen: az akkor már parlamenti pártként múködő LMP összesen 95 fô delegáltat tudott hadrendbe állítani ekkor. Az LMP mellesleg azért nem szerepel a vizsgálatomban, mert a párt nem tudott értelmezhető mértékú delegáltat felmutatni egyetlen választási esemény alkalmával sem.

Ahogy korábban jeleztem, tanulságos következtetéseket vonhatunk le, ha a fentieket kormány - ellenzék felosztásban vizsgáljuk meg, illetve ennek kapcsán kiemelten foglalkozunk azokkal a szavazókörökkel, ahol csak a Fidesz tudott pártdelegáltat mozgósítani.

A Fidesz példátlan hatékonysággal tudta megszervezni a szavazókörök felügyeletét, szinte alig találunk olyan választási eseményt és településkategóriát, ahol ne lett volna a mozgósítási hatékonyságuk $90 \%$ feletti. Ezzel szemben az ellenzék pártjai, lényegében a településhierarchia alacsonyabb fokai felé haladva, fokozatosan kopnak ki a szavazókörökből, habár például 2018-ban számos debreceni vagy székesfehérvári szavazókörnek sem volt ellenzéki biztosa. Ez a településméretből fakadó differenciáltság és térvesztés a 2019-es EP választás során volt a legszembetűnőbb, hiszen szervezetileg pont az a Jobbik roppant meg ekkorra, amely addig a kisebb településeken sok esetben egyedül képviselte az ellenzéket a szavazókörökben.

A delegálási potenciált vizsgáló kormány - ellenzék felosztásban tehát a településméretnek döntő jelentősége van, ami arra enged következtetni, hogy az ellenzéki pártok szervezeti fejletlensége pont a legkisebb településeken a leginkább tetten érhető. Említést érdemel, hogy van két másik mutató, amely választásról választásra ismétlődően, a településmérettel fordítottan arányosan nő; a Fidesz-KDNP pártlistás támogatottságának aránya, illetve a rontott szavazatok aránya. Előbbi jelenség már a 2002-es országgyűlési választásokon is jól látható volt, ami elsősorban az egykori FKGP szavazóbázis integrálásával magyarázható, utóbbira azonban nem tudok hasonló egzakt tudományos magyarázattal szolgálni. Ha elfogadjuk azt a feltevést, amelyre a tanulmány bevezetőjében is utaltam, mely szerint egy párt sikerének titka a helyi (fizikai) jelenlét, mely testet ölthet párttagokban, aktivistákban, helyi pártirodákban, akkor kézenfekvő a magyarázat, hogy a Fidesz-KDNP sikereit összekapcsoljuk a helyi pártdelegáltak szinte minden településre kiterjedő jelenlétével. 


\section{A helyi pártjelenlét és a választási eredmények közötti összefüggés}

Ha a vizsgált pártok eredményességét (listás szavazatarány) az alkalmazott településméret szerinti bontásban elemezzük, érdemes külön kezelnünk azon szavazókörök eredményeit, amelyekben az adott pártnak volt szavazatszámláló delegáltja. Ezzel szeretném empirikusan bizonyítani a helyi pártjelenlét és eredményesebb választási szereplés ok-okozati összefüggését. A szavazókörök nem szigetszerűen létező, önmagukban értelmezhető területi egységek, csupán egy választásról választásra életre hívott választástechnikai konstrukció. Természetesen egy ilyen vizsgálati megközelítés elsősorban a legkisebb, egy szavazókörrel rendelkező településekről adhatja a legreprezentatívabb képet, hiszen a választási eljárásról szóló törvény értelmében egy szavazókörre mintegy hatszáz, legfeljebb ezerötszáz, a központi névjegyzékben szereplő választópolgár juthat (2013. évi XXXVI. törvény a választási eljárásról 77. § (1)). Ennek megfelelően hazánk közel 1500 települése ún. egy szavazókörös község, így a szavazóköri szintú választási adatok, ebben az esetben a települési szintet is bemutatják.

A baloldali pártok esetében megállapítható, hogy minimális mértékben ugyan, de minden vizsgált választás alkalmával az összes településkategóriában jobban szerepeltek a „delegált” szavazókörökben, mint az adott településkategória összesített eredményei. Mindazonáltal, ezek valóban nagyon alacsony, rendre 1-2 százalékpont körüli vagy az alatti értékek. Nagyobb differenciáltságot csak a legkisebb népességú, így rendkívül alacsony elemszámú településkategóriák esetében tapasztalhatunk. A Demokratikus Koalíció esetében egy árnyalatnyival erősebben kirajzolódik a delegálttal rendelkező és összesített szavazóköri eredményeinek különbsége, ugyanakkor érdemes még egyszer hangsúlyozni, hogy a DK feleannyi szavazókörben sem tudott országosan pártjelenlétet biztosítani, mint a szocialisták.

A Jobbik esetében pontosan ugyanezt a megállapítást tehetjük; minden vizsgált választási esemény alkalmával eredményesebb volt saját maga településkategóriákon belüli értékeihez viszonyítva. A delegált és összesített adatok közötti eltérések ez esetben is minimálisak (1\% alattiak), azonban a pártdelegálttal rendelkező szavazókörök rendre kedvezőbb eredményeket hoztak a pártnak.

A kormánypártok esetében hasonló vizsgálat lefolytatását okafogyottá tette a 95-99\% körüli szavazóköri delegálási teljesítmény, így itt egy másik egyszerú eljárást alkalmaztam. Azon szavazókörök eredményeit külön elemeztem, ahol (a helyi választási bizottság tagjain kívül) kizárólag a kormánypártoknak ültek delegáltjai. Az összes magyarországi szavazókör 8,8\%-át jelentette ez 2014-ben (országgyúlési választások), 2018-ban már 12\%-ot, de az EP voksolások alkalmával pedig ez a szám jóval magasabb volt (2014: 21\%, 2019: 26\%). Ha ezen klaszter tagjait hasonló településméret kategóriákban vizsgáljuk, láthatjuk, hogy minden választási eseményen, az összes vizsgált település kategóriában a Fidesz-KDNP listás eredménye átlagosan 4-5 százalékponttal magasabb volt, mint az adott választáson az adott településkategórián belül mért eredmény (3. táblázat).

Ez alól egyetlen kivétel a 2014-es EP választások fővárosi adata, ahol minimálisan ugyan, de rosszabbul szerepelt a Fidesz-KDNP lista a pártdelegáltakkal rendelkező szavazókörökben. A szavazóköri pártdelegáltak adatait a 106 OEVK szintjére aggregálva is megállapítható az egyes pártok delegálóképességének markáns területi jellege, ami természetesen következik a fentebb bemutatott településméretből fakadó jellegzetességekből is. Az egyszerú Pearson korreláció adataiból próbáltam érzékeltetni a két OEVK szintû változó (listás szavazat \%, a szavazókörök hány \%-ában volt jelen az adott párt) közötti összefüggés erósséget (4. táblázat). 
A Fidesz-KDNP listás szavazataránya (\%) településtípusonként, valamint azokban a szavazókörökben, ahol csak a párt delegáltja foglalt helyet („csak Fidesz”).

The Fidesz-KDNP list vote share (\%) by type of settlement and in constituencies where only the party delegate was seated (,Fidesz only”).

\begin{tabular}{|c|c|c|c|c|c|c|c|c|}
\hline & \multicolumn{2}{|c|}{2014 EP } & \multicolumn{2}{|c|}{2019 EP } & \multicolumn{2}{|c|}{$\begin{array}{c}2014 \\
\text { országgyúlési }\end{array}$} & \multicolumn{2}{|c|}{$\begin{array}{c}2018 \\
\text { országgyúlési }\end{array}$} \\
\hline & $\begin{array}{c}\text { csak } \\
\text { Fidesz }\end{array}$ & $\begin{array}{l}\text { orszá- } \\
\text { gos }\end{array}$ & $\begin{array}{c}\text { csak } \\
\text { Fidesz }\end{array}$ & $\begin{array}{l}\text { orszá- } \\
\text { gos }\end{array}$ & $\begin{array}{c}\text { csak } \\
\text { Fidesz }\end{array}$ & $\begin{array}{l}\text { orszá- } \\
\text { gos }\end{array}$ & $\begin{array}{c}\text { csak } \\
\text { Fidesz }\end{array}$ & $\begin{array}{c}\text { orszá- } \\
\text { gos }\end{array}$ \\
\hline Budapest & 43,0 & 43,7 & 42,2 & 41,0 & 39,4 & 38,5 & 39,4 & 38,1 \\
\hline $20000-*$ & 51,1 & 48,9 & 51,3 & 48,2 & 46,6 & 40,3 & 47,6 & 43,6 \\
\hline $10000-20000$ & 58,8 & 52,9 & 54,9 & 52,8 & 51,6 & 44,0 & 52,5 & 47,3 \\
\hline 5000-10000 & 58,8 & 56,0 & 58,6 & 56,2 & 51,6 & 46,5 & 55,2 & 51,6 \\
\hline $1000-5000$ & 60,8 & 57,8 & 62,0 & 59,4 & 53,1 & 48,2 & 57,5 & 54,6 \\
\hline $500-1000$ & 62,6 & 60,7 & 65,9 & 63,5 & 54,5 & 50,8 & 60,6 & 58,3 \\
\hline-500 & 64,1 & 62,5 & 67,5 & 65,4 & 56,7 & 53,4 & 63,8 & 61,2 \\
\hline Magyarország & $\mathbf{5 9 , 7}$ & 51,5 & 60,9 & 51,9 & 52,2 & 43,5 & 56,1 & 47,4 \\
\hline
\end{tabular}

* Budapest nélkül

Forrás: NVI, saját szerkesztés

Source: NVI, own compilation

4. táblázat - Table 4

Pearson korreláció: Az egyes pártok listás támogatottsága (\%) és a pártdelegálttal rendelkező szavazókörök aránya az OEVK összes szavazókörén belül (\%).

Pearson correlation: List support for each party (\%) and the share of constituencies with party delegates in the total constituencies of the OEVK $(\%)$.

\begin{tabular}{|c|c|c|c|c|}
\hline & csak Fidesz & Jobbik & MSZP & DK \\
\hline 2014 országgyúlési & 0,37 & $-0,04$ & \multicolumn{2}{|c|}{0,33} \\
\hline 2014 EP & 0,58 & $-0,14$ & 0,14 & 0,41 \\
\hline 2018 országgyűlési & 0,45 & 0,21 & 0,45 & 0,58 \\
\hline $2019 \mathrm{EP}$ & 0,70 & 0,36 & 0,57 & 0,59 \\
\hline
\end{tabular}

Forrás: NVI, saját szerkesztés

Source: NVI, own compilation

A Fidesz-KDNP esetében a korábbiakhoz hasonlóan ez esetben is azoknak a szavazóköröknek a százalékos értékét vettem alapul, ahol kizárólag a kormánypárt delegáltjai voltak jelen. Az ő esetükben találjuk a legerősebb összefüggést, ez a 2019-es EP választások kapcsán (0.7) volt merhető. Ugyebár ekkor volt a legmagasabb azon szavazókörök száma országosan, ahová csak a Fidesz-KDNP volt képes delegálni (több mint minden negyedik szavazókör tartozott ebbe a csoportba ekkor). A Jobbik esetében is csak a legutóbbi EP voksolás kapcsán kapunk értelmezhető eredményt, amikorra már a párt által felügyelt szavazókörök száma országosan 28\%-ra zsugorodott. Ezzel szemben a baloldal pártjainál egy fokozatosan erősödő összefüggést tapasztalhatunk, habár a mért értékek még 
korántsem magyarázó erősségűek. Érdemes azt is rögzíteni, hogy a szocialisták abszolút számban szinte választásról választásra 5 ezer szavazókörben voltak képesek megjelenni, addig a DK egy nagyon komoly bővülésén ment keresztül szervezetileg ezen a téren (is). A Demokratikus Koalíció esetében megállapítható, hogy azokban az EOVK-kban szerepeltek átlagon felül, ahol szavazatszámláló biztosuk volt, így vélelmezhetőleg kiépült pártszervezettel is rendelkeztek 2019-re.

A kormánypártok 2-3 dél-dunántúli OEVK-t leszámítva (Baranya 3 - Mohács, Baranya 4 - Szigetvár, valamint Somogy 3 - Marcali) minden választókerületben legalább a szavazókörök 90\%-ában jelen tudtak lenni a választásokon. A Fidesz-KDNP szervezeti hatékonysága tehát ezen a vizsgálati szinten is egészen kimagasló, és csak az ország bizonyos térségeiben volt megközelíthetô az ellenzéki pártok számára.

A négy választási esemény adatainak vizsgálata után kijelenthető, hogy az ellenzék pártjainak számára a legnagyobb akadályt a Dunántúlon, de azon belül is kifejezetten a Nyugat-Dunántúl választókerületeiben való megjelenés jelentette. A Jobbik esetében közismert volt a párt kelet-magyarországi meghatározottsága, illetve annak nehézsége, hogy a nem kifejezetten válságtérségnek számító nyugati határszélen is eredményesen építkezzen (RónA D. 2017; TöLGYESSY P. 2015) (1. ábra).
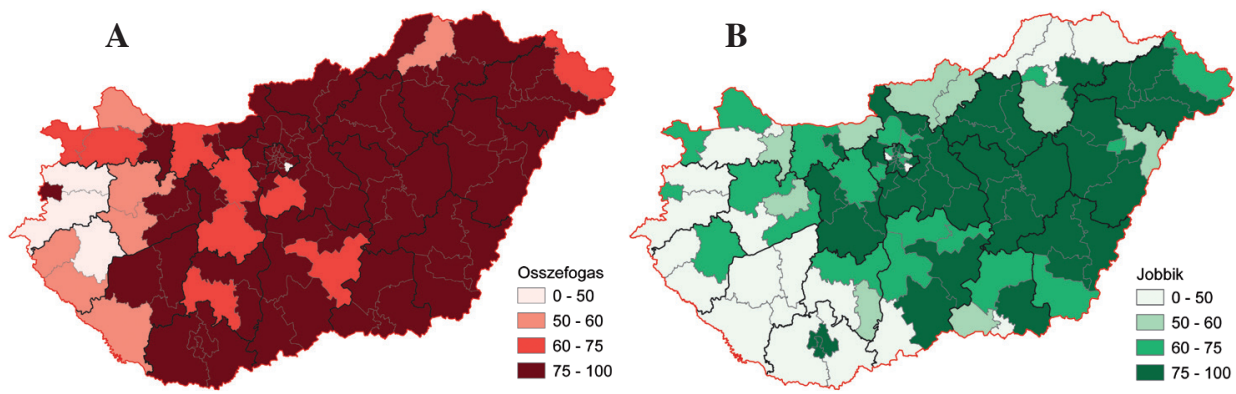

1. ábra Az Összefogás (A) és a Jobbik (B) delegáltjai az OEVK szavazóköreinek \%-ában a 2014-es országgyúlési választásokon. Forrás: NVI, saját szerkesztés.

Figure 1 Összefogás (A) and Jobbik (B) delegates in \% of the electoral districts of the OEVK in the 2014 parliamentary elections. Source: NVI, own editing.

A 2014-es országgyưlési választás alkalmával a szigetszerűen kiemelkedő szombathelyi és győri OEVK-t leszámítva a legtöbb nyugat-dunántúli választókerületben alig több, mint a szavazókörök 60\%-ban tudtak delegáltat küldeni. Ezzel szemben a Dunától keletre nagyon jó hatékonysággal tudták ezt a logisztikai feladatot megoldani a csereháti, gömöri aprófalvas térséget is magába foglaló Borsod-Abaúj-Zemplén megye 4-es OEVK-t leszámítva. 2018-ra ez a kép a baloldali pártok esetében jelentősen megváltozott, és azon választókerületek, amelyek szavazóköreinek legalább háromnegyedében ott tudtak lenni az MSZP delegáltjai, a megyeszékhelyek, valamint az Alföld központi részére szorultak vissza. A 2014-es baloldali összefogás másik pártja, a DK jóval kevesebb biztost delegált ekkor, és azok 40\%-a is Budapest szavazóhelyiségében foglalt helyet. OEVK szinten tehát elsósorban a fővárosban és annak agglomerációjában, valamint a Dunakanyar, illetve megyeközpontok választókerületeiben voltak jelen jelentősebb számban.

Jobbik a 2014-es országgyúlési választások alkalmával szintén az Alföld központi részein tudott a legeredményesebben mozgósítani a pártdelegáltakat, de ezen felül is elsôsorban Kelet-Magyarország egyéb területein volt hatékony (2 .ábra). Heves és Jász-NagykunSzolnok megyék összes választókerületében, legalább a szavazókörök háromnegyedében jelen volt a párt, de hasonló hatékonyság jellemezte ôket Békés és Szabolcs megyék majd- 
nem összes körzetében is. Ez a magterület jelentős átfedésben áll azzal a „Jobbik bázis” klaszterként hivatkozott térséggel, amit a korábban citált választási földrajzi tanulmányok, a választási eredmények alapján beazonosítottak (VIDA Gy.-KovÁcs Z. 2017. illetve VIDA Gy.-KovalcsiK T. 2018). 2018-ra ez a térszerkezet nem módosult jelentősen a Jobbik esetében. Több dunántúli területen felsejlik a párt eredményes szervezetépítése (pl. Somogy és Fejér megye), mindazonáltal a Jobbik kapcsán is megállapítható, hogy Nyugat-Dunántúlon az egyik vizsgált időpontban sem tudtak eredményesen delegálni.
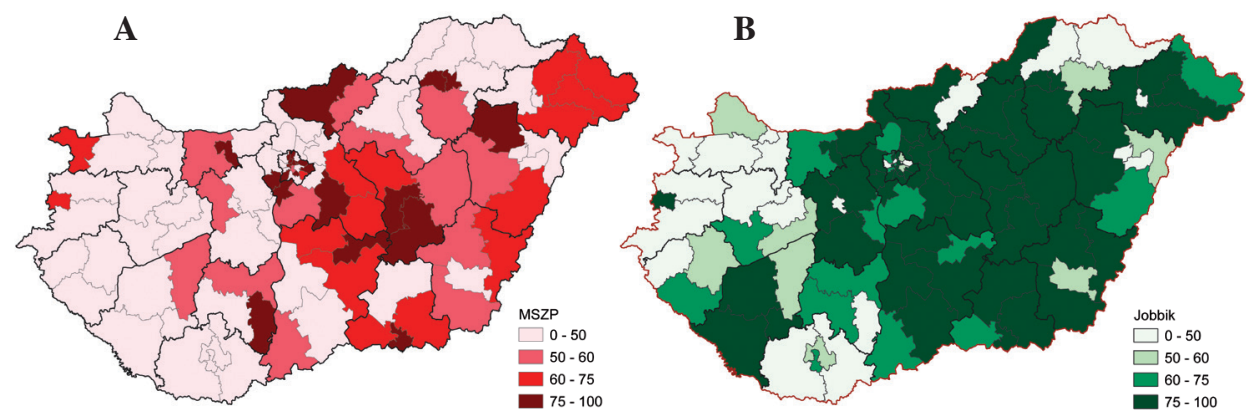

2. ábra Az MSZP (A) és a Jobbik (B) delegáltjai az OEVK szavazóköreinek \%-ában a 2018-es országgyúlési választásokon. Forrás: NVI. saját szerkesztés.

Figure 2 MSZP (A) and Jobbik (B) delegates in \% of OEVK constituencies in the 2018 parliamentary elections. Source: NVI. own editing.

Mintegy a fentiek eredőjeként aligha meglepő, hogy a csak Fidesz-KDNP által „felügyelt" szavazókörök százalékos aránya az egyes OEVK-kon belül pont a Nyugat-Dunántúl régiójában a legkirívóbb (3. ábra). Mindkét vizsgált országgyúlési választás esetén a Vas megye 2-es és 3-as OEVK-k voltak azok, amelyekben a szavazókörök több mint felében csak a kormánypárt rendelkezett pártdelegálttal. A szombathelyi OEVK-t leszámítva, szinte az összes ezekkel határos választókerületben is relatív magas ezen szavazókörök aránya (25-50\%). A 2018-as választások idejére nem módosul jelentősen ez a térszerkezet, azonban számos alföldi OEVK is „,csatlakozik” a relatíve magas, kizárólag a kormánypártok által delegált szavazókörökkel rendelkezők csoportjához. Mindkét vizsgált időpontban, Északkelet-Magyarország aprófalvas választókerületében is viszonylag magas volt a csak Fidesz delegálttal rendelkező szavazókörök aránya.

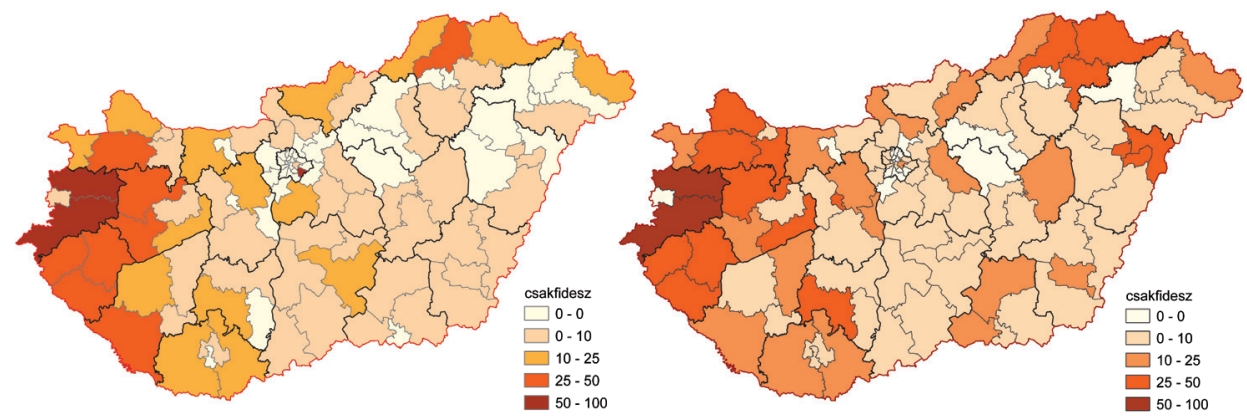

3. ábra A csak Fidesz-KDNP által delegált szavazókörök arány (\%) az OEVK összes szavazókörén belül, a 2014-es és 2018-as országgyúlési választásokon. Forrás: NVI, saját szerkesztés.

Figure 3 The proportion of Fidesz-KDNP-only constituencies (\%) within the total constituencies of the OEVK in the 2014 and 2018 parliamentary elections. Source: NVI, own editing. 


\section{Összefoglalás}

Vizsgálatom elsődleges célja, a hazánk politikai színterét meghatározó pártok, szervezeti fejlettsége területi különbségeinek feltárása volt. Azok a korábbi nemzetközi kutatások, melyek a magyar pártosodás folyamatát, valamely kvantitatív módszer felhasználásával kívánták, a térség poszt-szocialista országainak kontextusában vizsgálni, rendre az adathiány akadályába ütköztek. Ennek egyik oka a hazai pártrendszer viszonylagos fejlettlensége, ami a párttagok és alapszervezetek relatív alacsony számában fejeződik ki (Riberio P.F.-LocATElli F. 2019), továbbá maguk a pártok sem szeretnek ilyen jellegú adatokat közölni, ami szintén nem magyar, sokkal inkább térségi kulturális sajátosság (TAVITS M. 2012). Annak megértése, hogy pártjaink Magyarország egyes vidékein, eltérő mértékú társadalmi beágyazottságra tettek szert, azért is fontos, mert számos fentebb idézett nemzetközi példa mutatja, hogy a sikeres választási szereplés alapfeltétele (nem kizárólagosan ugyan) a helyi jelenlét, pártszervezet megléte. A politikai élet szereplői mindazonáltal akkor lesznek képesek szélesebb választói rétegek számára releváns társadalmi problémákra érdemben reagálni, ha az ország minden vidékére rálátó szervezeti struktúrával rendelkeznek.

Ebben a tanulmányban a pártok társadalmi beágyazottságát a négy vizsgált országos jelentőségú választás során a szavazókörökbe delegált biztosok adatain keresztül próbáltam kitapintani. A kormányoldal hatékonysága (szavazókörök 95-99\%-a) választásról választásra oly mértékben kiemelkedő, hogy gyakorlatilag alig enged teret bármiféle érdemi területi vizsgálatnak. Így ezzel a politikai szereplővel kapcsolatban annyit állapíthatunk meg, hogy településmérettől és a választókerület földrajzi elhelyezkedésétől függetlenül, a társadalom minden rétegében jelen van egy nagyon hatékony pártszervezettel. A választási eredmények összevetését ezért azokra a szavazókörökre szúkítettem, ahol kizárólag a Fidesz-KDNP delegáltjai voltak jelen. Ebben a szegmensben a párt még a saját maga az adott településtípuson belül mért eredményeit is képes volt átlagosan 4-5\%-ponttal meghaladni, ami jól mutatja a kiépült pártszervezeti háló fontosságát.

Ellenzéki oldalon már egy jóval differenciáltabb képet láthattunk. Ennek van egy horizontális, a településméretből fakadó vetülete is, mely szerint a települési hierarchián lefelé haladva egyre kisebb pártjelenlétre számíthatunk. Ez különösen igaz a baloldal pártjaira, míg a Jobbik számottevő pártszervezeti hálóval rendelkezhetett az alacsonyabb népességú településeken is. Az ellenzéki pártok választói támogatottsága is erősen eszerint a település lélekszámából fakadó dinamika mentén alakult, ugyanakkor ha kizárólag az általuk „delegált" szavazókörök adatait vesszük számításba, látható, hogy 1-2 százalékpontos többletet jelentett egy pártdelegált megléte. A Jobbik esetében érdemes kiemelni, hogy a párt kifejezetten a közepes méretú (5-20 ezer lakosú) településeken tudott hatékonyan delegálni, de a legkisebb lakosságszámú település kategóriában is számottevő delegáltat tudott felvonultatni, amire a baloldal pártjai már nem voltak képesek.

A differenciáltság másik dimenziója földrajzi természetû, amelyet OEVK szinten igyekeztem tetten érni. Âltalánosságban kijelenthető, hogy az ellenzék pártjait jóval gyengébb jelenlét jellemezte a Dunántúlon, de különösen a Nyugat-Dunántúli régióban szembetűnő szervezeti gyengeségük, ugyanakkor a perifériás elhelyezkedésú, döntően aprófalvas északkelet-magyarországi választókerületekben is feltűnőek ezek a szervezeti hiányosságok.

Összeségében megállapítható, hogy ha a szavazókörökbe delegált szavazatszámláló biztosok adatain keresztül definiáljuk a helyi pártjelenlétet, ez eképpen definiált jelenlét hozzájárul az adott párt jobb választási eredményéhez. Különösen igaz ez abban az esetben, ha kizárólag egyetlen párt delegáltja múködik egy adott szavazókörben (településen). 
Ebben az értelemben a nemzetközi szakirodalomban lefektetett hipotézis, még ha nem is túl erôsen, de bizonyítható volt empirikus úton hazánk esetében is.

Az elmúlt 15-20 év tapasztalatai azt mutatják, hogy térségünkben azok a pártok tudnak sikeresek lenni (legalábbis állva maradni a harcmezőn), akik komoly munkát fektettek a pártszervezeti háló megszövésébe (TAVITS M. 2012). Nem szabad figyelmen kívül hagyni persze a megfelelő politikai légkör meglétét sem, amely mintegy alapfeltétele, katalizátora egy számottevő és országos hatósugárú mozgalmi munkának. A Fidesz-KDNP gyakorlatilag 2006 őszétől tartó példátlan választási sikersorozatának számos összetevője ismert, illetve állandó közéleti vita tárgyát képezi. A 2002-es választási kudarc olyan energiákat szabadított fel, mely a polgári körök mozgalma és a gyakorlatilag abszolút mértékben a pártelnök kezébe adott teljhatalmú pártirányítási jogosítványokon keresztül (BÉKÉs M. 2009), egy hallatlanul hatékonyan múködó politikai-szervezeti gépezetet felépítését eredményezte. A Fidesz tehát jól ismerte fel és használta ki a 2002 utáni társadalmi felhajtóerőket és tudatos szervezetépítésbe kezdett (társszervezetek bevonásával; pl. MAGOSZ, egyházak stb.), ami sok szempontból mintaadó. A tudatos közösségépítés technikái terén (választók személyes elérésére koncentráló szervezeti háló megépítése) szintén mértékadónak mondható a magyar politikai életben az, amit a Fidesz 2003-tól kezdődően végigcsinált (BALÁZS Z.-HAJdú A. 2017).

A kormányon lévő politikai oldal társadalmi beágyazottságának mértéke, különösen hazánk vidéki területein, kimagasló, még ha történelmi szempontból nem is példa nélküli. Ennek kvantitatív alátámasztására meglátásom szerint kiválóan alkalmas az általam használt szavazóköri pártjelenlét.

Létezik azonban egy olyan tényező is, amelynek megemlítése nem megspórolható vizsgálatom szempontjából, ugyanakkor adatok tekintetében jóval nehezebb tetten érni. Többek szerint (KovÁCH et al. 2020) a kormányoldal sikerének egyik kulcsát azok az informális hálózatok jelentik, amelyek már nem is írhatók le azokkal a hagyományos pártos intézményesültségi kritériumokkal, melyekre az idézett nemzetközi szerzők hivatkoznak. A mai mediatizált világban, a politika ma úgy képes hatékony üzenetközvetítésre a választók felé, hogy helyi szinten nincs rászorulva a politikai integráció közvetlen lokális formáira, tehát a helyi közösségekre (lásd, polgári körök megszűnésé). A magyar, politikai értelemben is egy egyre inkább felülről integrált társadalom (HuSzÁr Á.-SzABó A. 2020.), amelyben maguk a politikai szereplők képesek azokat az identitáshordozó témákat szolgáltatni, amelyek mentén a választók pártpreferenciális döntéseket hoznak. Ez ma ugyan úgy igaz az ellenzékre, mint a Fidesz-re, csak utóbbi, itt most be nem mutatott okoknál fogva, ezt sokkal hatékonyabban tudja megtenni.

A Jobbik, a 2006 őszét követő politikai feszültség, valamint a 2008 utáni társadalmi-gazdasági krízis hullámain tudott egy szinte példátlan nagyságú vidéki pártszervezetet felépíteni és sokáig viszonylag eredményes múködtetni. Ebben persze kulcsszerepet játszott a Magyar Gárda felállítása is, de tény, hogy a pártnak 2010-re már közel ezer alapszervezete múködött országszerte (RónA D. 2017). A vizsgálatomban használt indikátort alapul véve kijelenthető, hogy a Magyar Szocialista Párt még mindig a hazai baloldal legszerteágazóbb szervezeti hálójával rendelkező pártja. Az MSZP delegáltjai nagyjából állandó számban, a hazai szavazókörök csaknem felében képviselik pártjukat. A szocialisták viszonylagos szervezeti fejlettsége, már a 2014-es választásokat megelőzően is beszédtéma volt a hazai politikai nyilvánosságban, habár ekkor már olyan nem pártos, de alapvetően a hazai progresszív vagy baloldali ideológiákat nyíltan felvállaló civil mozgalmak is szárba szökkentek, mint a Milla vagy a Szolidaritás. A későbbi választási együttműködés megindoklásának egyik legszemléletesebb példája az alábbiak szerint volt olvasható a Magyar Narancs hasábjain 2013-ban (Magyar Narancs, 2013 március 1.) „Az MSZP és az Együtt 
2014 - Erögyüjtési szakasz”: „Az MSZP megkerülhetetlen tényező. Olyan szervezeti háttérrel rendelkezik, amilyen a baloldalon még közelitóleg sincs senkinek, és amely életfontosságú egy olyan ajtótól ajtóig zajló kampányban, mint amilyenre most számítani lehet."

A kedvező belpolitikai légkör (NOlimpia kampány és a 2019-es EP választások sikere) akár hasonló felhajtóeróként hathatott volna hazánk legújabb politikai szereplőjére, a Momentum Mozgalomra is, azonban az általam használt mutató alapján a párt szinte alig tudott vizsgálatra érdemes számú delegáltat felvonultatni a 2019-es EP választások alkalmával (313 db szavazókörben). Beszédes, hogy a párt, a delegáltjainak csaknem felét Budapesten mozgósította és mindössze 20 darab községi jogállású település szavazókörében volt jelen. Ha a szavazatszámláló biztosok adatain keresztül próbáljuk tetten érni a párt szervezeti fejlettségét, a Momentum kapcsán arra kell következtessünk, hogy még nagyon a pártinfrastruktúra kiépítésének az elején járnak, vagy szimplán az online politikai hadviselés eszközeiben bízva próbálnak meg üzeneteket eljuttatni a választókhoz. Az általam idézett nemzetközi tanulmányok egybe csengő megállapításai szerint, ez nem lesz egy hosszútávon jól kifizetődő taktika.

Térségünk pártjai, még mindig egy viszonylag fiatalnak mondható demokratikus berendezkedésben versenyeznek egymással. Azonban még a legmintaadóbb parlamentáris demokráciákban is, arra vannak kényszerítve ezek a versengő pártok, hogy folyamatosan felülvizsgálják és megújítsák azokat a gyakorlatokat, amelyek a pártszervezet fejlesztésére irányulnak (Scotт J. - WiLls J. 2017). Az idézett nemzetközi szerzők egybehangzóan állítják, hogy még a megváltozott médiafogyasztási és technológiai viszonyok mellett is, hatékony kampányokat és ezáltal jó választási eredményeket nagyon nehezen lehet elérni, egy helyben jól funkcionáló pártszervezet nélkül. Az általam elvégzett összevetésben különösen ott nyert megerősítést ez az elmélet, ahol az egyik politikai szereplő képviselete kizárólagos volt. Ha a jelenlegi kétosztatú politikai színtérre egyszerúsítjük a képletet, akkor kijelenthető, hogy ha Magyarország csak azokból a szavazokörökből állna, ahol kizárólag a Fidesz-KDNP volt képviseltetve, választásról-választásra, a kormánypártok átlagosan $8 \%$ ponttal jobb eredményt értek volna el listán. Mindeközben az ellenzéki pártok esetében, a pártdelegált jelenléte átlagosan $1 \%$ körüli szavazattöbbséget jelentett országosan. A vizsgált településkategóriákon belül is csak a baloldali pártok esetében mutatható ki ennél nagyobb többlet, jellemzően a legalacsonyabb népességú településeket tömörítő csoportokban, ahol amúgy is alacsony volt a delegált szavazókörök száma.

MARGIT TAViTs kutatási eredményeit, nem csak azért tartom fontosnak, mert annak fókuszába több poszt-szocialista ország mellett hazánk is bekerült, hanem mert figyelembe vette az önkormányzati választások pártos indulóit is (1990-2010 között). Így formai hasonlóságokat is mutat az általam használt módszertannal, abban az értelemben, hogy közvetlenül a választások során keletkező adat alapján közelíti a pártjelenlétet. Megállapítja, hogy a választókerületi szinten, ott tudtak jobb eredményt elérni a vizsgált magyar pártok (átlagosan 5\% ponttal), ahol az átlagosnál nagyobb számban voltak önkormányzati indulói. Egy hasonló kutatás időbeli kiterjesztése a 2010 utáni időszakra, ennek a vizsgálatnak is, egy ígéretesnek tûnő új iránya lehet.

Bódi MÁTYÁs

ELTE, TTK, FFI, Etnikai- és Vallásföldrajzi Mühely

bodimatyas@gmail.com 


\section{IRODALOM}

BALÁzs Z.-HAJdú A. 2017: A Fidesz - Magyar Polgári Szövetség a magyar politikában - In. Trendek a magyar politikában - 2; A Fidesz és a többiek: pártok, mozgalmak, politikák (szerk BoDA Zs.-SzABó A.), MTA TK Politikatudományi Intézet, pp. 83-109.

BASEdAu M.-STROH. A. 2008: Measuring Party Institutionalization in Developing Countries: A New Research Instrument Applied to 28 African Political Parties - GIGA (German Institute of Global and Area Studies) - Working Papers, 69. pp. 1-28.

BÉKÉs M. 2009: Pártirányítás - Irányított párt: A Fidesz szervezeti változásainak hatása a párt centralizációjára (1988-2008). TDK-dolgozat. Budapest: Budapesti Corvinus Egyetem.

Bódi F.-Bódi M. 2011: Hol vannak a választók? - Politikatudományi Szemle, 20. 1. pp. 51-74.

EBESZ/ODIHR 2014: Limited Election Observation Mission Final Report: Parliamentary Elections 6 April 2014 in Hungary, 32 p.

EBESZ/ODIHR 2018: Limited Election Observation Mission Final Report: Parliamentary Elections 8 April 2018 in Hungary, 33 p.

ENYEDI Zs.-KÖRÖSÉNYI A. 2001: Pártok és pártrendszerek. - Osiris Kiadó, Budapest 304 p.

ENYEDI Zs. 2004: A voluntarizmus tere. A pártok szerepe a törésvonalak kialakulásában. - Századvég (Új Folyam) 33. pp. 5-26.

Frendreis, J. P.-Gibson J L.-LAura L. V. 1990. „The Electoral Relevance of Local Party Organizations.” American Political Science Review 84. 1. pp. 225-235.

GERGHINA S. 2014: Shaping parties' legitimacy: Internal regulations and membership organisations in post-communist Europe - In. International Political Science Review / Revue internationale de science politique, 35. 3. pp. 291-306.

HAJDÚ Z. 2006: A 20. századi magyar parlamenti választások választási földrajzi kérdései - Múltunk, 2006/1. pp. 137-169.

HALVORSEN S. 2020: The geography of political parties: Territory and organisational strategies in Buenos Aires - Transaction of the Institute of the British Geographers, 2020, 45. 2. pp. 242-255.

Huszár Á.-SzABó A. 2020: Pártszimpátia és a társadalmi mobilitás érzékelése. In. KovÁcH I. 2021: Mobilitás és integráció a magyar társadalomban. Társadalomtudományi Kutatóközpont - Argumentum Tudományos Kiadó, Budapest, pp. 11-34.

JANKÓ F.-KOMORNOKI M. 2008: Szuburbanizáció és választási földrajz: átalakuló pártválasztás Budapest térségében - Tér és Társadalom 22. 4. pp. 115-134.

KÁKAI L.-VETő B. 2019: Állam vagy/és Önkormányzat - Adalékok az önkormányzati rendszer átalakításához. - Politikatudományi Szemle 28. 1. pp. 17-41.

KovÁcH I. 2021: Mobilitás és integráció a magyar társadalomban. Társadalomtudományi Kutatóközpont - Argumentum Tudományos Kiadó, Budapest, 371 p.

KovÁCs Z. 1991: Az 1990. évi parlamenti választások politikai földrajzi tapasztalatai - Földrajzi Értesítő, 40. 1-2.pp. pp. 55-80.

KÖRÖSÉNYI A.-GyUlAi A.-ILLÉS G. 2020: Az Orbán-rezsim - A plebiszciter vezérdemokrácia elmélete és gyakorlata. - OSIRIS Kiadó, Budapest, 256 p.

LAKNER Z. 2017: Megújuló válság. Az MSZP alkalmazkodási kísérlete 2010 után - In. Trendek a magyar politikában - 2; A Fidesz és a többiek: pártok, mozgalmak, politikák (szerk. BodA Zs.-SzABó A.), MTA TK Politikatudományi Intézet, pp. 143-167.

LÁszLó R. 2018: Nem hozott a külhon mandátumot a Fidesznek, a „győzteskompenzációval” együtt viszont 7-et is - In. Választásirendszer.hu http://www.valasztasirendszer.hu/?p=1943608\&fbclid=IwAR0y_Hq4tOrZanWhZOvlNvI5gRsz-DpRsmpl_ X670zF4Lccj71-v7f3Aj8s

Mikola B.-Oross D. 2018: Egy pártszervezet két arca. A mozgalmi pártok belső feszültségei az Öt Csillag Mozgalom példáján keresztül - In. Politikatudományi Szemle, 2018. 27. 1. pp. 65-90.

Pete M. 2016: Határképző identitások - identitást képző határok. - Földrajzi Közlemények.pp. 296 -311.

PÁLné KovÁcs I. 2019: Az önkormányzati választások elé - In. Karátson Gábor Kör előadása: 2019. október 11. https://okopolitika.hu/szabadegyetem/36-az-onkormanyzati-valasztasok-ele

RiBERIO P. F. - LOCATELLI F. 2019: Time after time: party organizational strength in new and old democracies. - Opin. Publica 2019. 25. 1. pp. 23-32.

RónA D. 2016: Jobbik-jelenség. A Jobbik Magyarországért Mozgalom térnyerésének okai. - KUK Könyv és Kávé Kiadó, Budapest 314 p.

SCHIFFER A. 2018: „Gyurcsány Ferenc egyetlen igazsága” - In: ScHIFER A.: Zöld Jelzés, Kaligram Kiadó, Budapest, pp. 402-404.

SCOTT J.-WILLS J. 2017: The geography of the political party: Lessons from the British Labour Party's experiment with community organising, 2010 to 2015 - Political Geography, 2017, 60. 3. pp. 121-131. 
STUMPF A. 2021: Így nyerne a Fidesz Budapest nélkül - a vidéki pénzszórás háttere. Válasz Online: https://www.valaszonline.hu/2021/01/21/fidesz-ellenzek-valasztas-videk-lazar-janos-csanyi-sandor/

SzIGETI P. 2013: A magyar választási rendszer átalakítása - összehasonlítható - Jogtudományi Közlöny, 69. 2. pp. 82-92.

Tavits M. 2012: Post-Communist Democracies and Party Organization. - Cambridge University Press, New York, $241 \mathrm{p}$.

Tavits M. 2014: Post-Communist Democracies and Party Organization - In. Journal of Politics, 76. 3. 2014. pp. 1-22.

TóKA G. 1991: „Választási eredmények elemzése.” - In: Hol tart a szabad gondolat? Szerk. GYEKICZKi ANDRÁs. Budapest: Politikai Tanulmányok Intézete, pp. 65-92.

Tо́тн Cs. 2017: Választási rendszer és választások 2014-ben - In. Trendek a magyar politikában - 2; A Fidesz és a többiek: pártok, mozgalmak, politikák (szerk BoDA Zs.-SzABó A.), MTA TK Politikatudományi Intézet, pp. 43-60.

TÖLGYESSY P. 2015: A magyar társadalom válságának újabb stációja - In. Ökopolisz Alapítvány: https://www.youtube.com/watch?v=vck01u7rpWM

TÖLGYESSY P. 2019: „Mára a '89-es példakép is bajba került” - Ellensúly Közéleti Folyóirat, Budapest, 4. 3. pp. $4-27$.

TÖRöK G. 2019: Török Gábor politikai elemző az InfoRádió Aréna címú músorában 2019. október 14-én: https://www.youtube.com/watch?v=vUqCpHI8fsQ

VIDA GY.-KovÁCS Z. 2017: Magyarország átalakuló választási földrajza a 2010-es és a 2014-es parlamenti választások tükrében. - Földrajzi Közlemények 141. 2. pp. 125-138.

VIDA Gy.-KovalcsiK T. 2018: Magyarország választási földrajzi sajátosságai a 2014-es és a 2018-as parlamenti választások tükrében. - Modern Geográfia, 13. 4. pp. 15-30.

VIDA Gy. 2020: A magyar országgyúlési választási rendszer földrajzi torzulásainak vizsgálata - Doktori (PhD) értekezés, Szegedi Tudományegyetem Természettudományi és Informatikai Kar Földtudományok Doktori Iskola Gazdaság- és Társadalomföldrajz Tanszék, 127.p. 